\title{
FRAKSINASI SENYAWA PENGHAMBAT ENZIM $\alpha$-GLUKOSIDASE DARI EKSTRAK ETANOL DAUN SAMBUNG NYAWA (Gynura procumbens (Lour) Merr.)
}

\author{
Marwati, Subehan Lallo, Yusnita Rifai \\ Fakultas Farmasi, Universitas Hasanuddin, Makassar
}

Kata Kunci :

G. procumbens, Fraksinasi, $\alpha$-Glukosidase, Diabetes Melitus

\begin{abstract}
ABSTRAK
Daun sambung nyawa (Gynura procumbens(Lour) Merr) merupakan salah satu tanaman yang memiliki senyawa yang berpotensi sebagai penghambat enzim $\alpha$-glukosidase atau sebagai obat antidiabetes melitus. Penelitian ini bertujuan untuk memisahkan senyawa yang memiliki aktivitas penghambatan enzim $\alpha$-glukosidase dan mengetahui jenis kinetika penghambatan berdasarkan grafik Lineweaver-Burk. Pemisahan senyawa berdasarkan tingkat kepolaran pelarut. Uji aktivitas dilakukan pada ekstrak etanol, Fraksi n-heksan fraksi etil asetat dan fraksi air, dan kontrol positif acarbose yang diukur dengan micro plate reader pada panjang gelombang $405 \mathrm{~nm}$. Hasil penelitian menunjukan bahwa nilai IC50 berturutturut pada ekstrak etanol 6,56 ppm, fraksi n-heksan sebesar 14,97 ppm, fraksi etil asetat 9,33 ppm, fraksi air 13,03 ppm dan acarbose 6,38 ppm serta mekanisme kinetika penghambatan enzim secara uncompetitive.
\end{abstract}

\section{PENDAHULUAN}

Indonesia sebagai negara tropis memiliki beraneka ragam tumbuhan yang dapat dimanfaatkan sebanyak-banyaknya untuk kepentingan manusia. Masyarakat Indonesia sejak zaman dahulu telah mengenal tanaman yang mempunyai khasiat obat atau menyembuhkan berbagai macam penyakit. Tanaman yang berkhasiat obat tersebut dikenal dengan sebutan tanaman obat tradisional (1).

Penggunaan obat tradisional secara luas oleh masyarakat disebabkan selain karena alami, mudah didapat, serta harganya yang murah, penggunaan obat ramuan tumbuhan secara tradisional ini tidak menghasilkan efek samping yang ditimbulkan seperti yang sering terjadi pada pengobatan secara kimiawi, selain itu masih banyak orang yangberanggapan bahwa penggunaan obat tradisional lebih aman dibandingkan dengan obat sintesis (2).

Banyak penelitian yang membuktikan bahwa berbagai senyawa dalam tumbuhan berpotensi sebagai penghambatan enzim $\alpha$-glukosidase. Salah satu tanaman yang memiliki aktivitas sebagai inhibitor enzim $\alpha$-glukosidase, salah satunya adalah tanaman daun sambung nyawa (Gynura procumbens (Lour) Merr.) dan daun sambung nyawa juga merupakan salah satu tanaman obat tradisional yang diketahui secara empiris memiliki khasiat untuk menyembuhkan diabetes melitus (3).

Diabetes melitus merupakan penyakit gangguan metabolik menahun akibat rusaknya pankreas yang tidak mampu memproduksi insulin dalam jumlah yang mencukupi atau tubuh tidak mampu menggunakan insulin yang telah diproduksi dengan sebagaimana mestinya (4).
Indonesia merupakan negara ke-4 dengan prevalensi penderita diabetes tertinggi setelah Cina, Amerika dan India. Data WHO memperkirakan jumlah penderita diabetes melitus tipe 2 di Indonesia akan meningkat signifikan hingga 21,3 juta jiwa pada 2030 mendatang (5).

Pengobatan diabetes melitus merupakan pengobatan yang terus-menerus dan menahun. Pengobatan diabetes melitus yang sering digunakan adalah dengan menggunakan obat oral. Salah satu mekanisme kerja obat antidiabetes adalah sebagai inhibitor katabolisme karbohidrat, yaitu enzim $\alpha$-glukosidase. Inhibitor $\alpha$ glukosidase bekerja menghambat enzim $\alpha$ glukosidase yang terdapat pada dinding usus halus. Inhibisi kerja enzim ini secara efektif dapat mengurangi pencernaan karbohidrat kompleks, sehingga memperlambat absorbsi glukosa ke dalam darah dan mengurangi peningkatan kadar glukosa setelah makan pada penderita diabetes melitus. Kerja enzim ini tidak menyebabkan efek samping hipoglikemik (6).

Aktivitas yang dimiliki oleh daun sambung nyawa ini dipengaruhi oleh senyawa yang terkandung didalamnya seperti penelitian yang telah dilakukan oleh (3), disebutkan bahwa daun sambung nyawa memiliki kandungan senyawa kimia yaitu asam kafeat, asam vanilat, asam para kumarat, asam para hidroksi benzoat, polifenol, dan kaemferol dan penelitian yang dilakukan oleh (7) disebutkan bahwa ekstrak etanol daun $G$. procumbens dengan dosis 50, 150 dan $300 \mathrm{mg} / \mathrm{kg}$ dapat menurunkan kadar glukosa darah tikus DM yang diinduksi streptozotosin (STZ). Ekstrak etanol daun $G$. procumbens menunjukkan efektivitas yang lebih baik dibandingkan ekstrak 
air dalam menurunkan kadar glukosa darah tikus yang diinduksi STZ

Oleh karena itu, penelitian ini bertujuan untuk mengisolasi senyawa yang memiliki aktivitas penghambatan enzim $\alpha$ glukosidase dan mengetahui jenis kinetika penghambatan berdasarkan grafik Lineweaver-Burk.

\section{METODE PENELITIAN}

\section{Alat dan Bahan}

Alat-alat yang digunakan pada penelitian ini adalah bejana maserasi, cawan porselin, eksikator, oven, labu ukur, mikropipet, pipet tetes, Lemari Pengering, Chamber, rotary evaporator (IKA), kolom chromatography vakum (Buchi), seperangkat FT-IR (Bruker ${ }^{\circledR}$ ), seperangkat alat spektrofotometer UV-Vis, lampu UV (254 nm dan $365 \mathrm{~nm}$ ), Elisa Reader (Biotex ELX), mikro pipet (socorex, Eppendorf), plate well 96 lubang, $\mathrm{pH}$ meter, dan timbangan analitik (Sartorius).

Bahan yang digunakan pada penelitian ini adalah daun Gynura procumbens, aquadest, pereaksi mayer, pereaksi wagner, pereaksi dragendorf, metanol, etanol $70 \%$, etil asetat, $\mathrm{H}_{2} \mathrm{SO}_{4} 10 \%$, kloroform, lempeng silika gel 60 GF 254, Lempeng KLTP, pereaksi Lieberman-Burchard, n-heksan, spiritus, serbuk $\mathrm{Mg}$, fecl, $\mathrm{H}_{3}$ HCL pekat, buffer fosfat, dimetil sulfoksida (DMSO), p-nitrofenil- $\alpha$-D-glukopiranosida (pNPG) (sigma Aldrich,USA), Akarbose (glucobay), Natrium karbonat $\left(\mathrm{Na}_{2} \mathrm{CO}_{3}\right)$ (Merck), dan enzim $\alpha$-glukosidase (sigma Aldrich,USA).

\section{Prosedur Kerja}

\section{Penyiapan Sampel Penelitian}

Sampel daun sambung nyawa (G. procumbens) yang diperoleh dari daerah Banta-Bantaeng, Kota Makassar, Sulawesi Selatan. Sampel daun sambung nyawa dicuci dengan air mengalir, kemudian disortasi basah, dipotong kecil-kecil, kemudian dicuci bersih dengan air mengalir lalu dikeringkan dalam Lemari pengering simplisia hingga kering, selanjutnya dilakukan ekstraksi. Ekstraksi dilakukan dengan cairan penyari yaitu etanol $70 \%$. serbuk simplisia daun sambung nyawa sebanyak 1000gram dimasukkan dalam bejana maserasi, Kemudian cairan penyari ditambahkan sebanyak 5 liter ke dalam bejana maserasi. Ekstraksi dilakukan selama $3 \times 24$ jam pada suhu kamar, terlindung dari cahaya matahari, dan diaduk sesekali. Setelah 3 hari kemudian disaring, filtrat diuapkan dengan cara dirotari evaporator hingga diperoleh ekstrak Kental.

\section{Penyiapan Sampel Uji}

\section{Pembuatan Dapar Fosfat pH 6,8}

Sebanyak 1,778 gram $\mathrm{Na}_{2} \mathrm{HPO}_{4}$ dan 1,56 gram $\mathrm{NaH}_{2} \mathrm{PO} 4$ masing-masing dilarutkan kedalam labu ukur $100 \mathrm{~mL}$ dengan aquadest bebas $\mathrm{CO}_{2}$ kemudian cukupkan hingga batas labu ukur, campur larutan $\mathrm{Na}_{2} \mathrm{HPO}_{4}$ dan $\mathrm{NaH}_{2} \mathrm{PO}_{4}$ kemudian ukur $\mathrm{pH}$ nya hingga $\mathrm{pH} 6,8$.

\section{Pembuatan Dapar Fosfat pH 6,8}

Larutan substrat dibuat dengan menimbang 37,5 mg pNPG dan dilarutkan dalam dapar fosfat hingga $25 \mathrm{~mL}$. Sehingga diperoleh konsentrasi $5 \mathrm{mM}$.

\section{Pembuatan Larutan Enzim a-Glukosidase}

Larutan enzim dibuat dengan menimbang 1,3 mg enzim $\alpha$ glukosidase dan dilarutkan dalam $50 \mathrm{~mL}$ dapar fosfat $\mathrm{pH}$ 6,8 dalam kondisi dingin, hingga diperoleh konsentrasi larutan enzim $0,5 \mathrm{U} / \mathrm{mL}$.
Pembuatan Larutan Natrium Karbonat 200 mM

Larutan natrium karbonat $200 \mathrm{mM}$ dibuat dengan menimbang 2,12 g serbuk natrium karbonat dan dilarutkan dengan aqudest hingga $100 \mathrm{~mL}$.

\section{Pembuatan Larutan Acarbose}

Larutan acarbose konsentrasi 100 ppm dibuat dengan menimbang $1 \mathrm{mg}$ serbuk standar acarbose, kemudian dimasukkan kedalam labu ukur $10 \mathrm{~mL}$ dan dilarutkan dalam dapar fosfat pH 6,8 hingga $10 \mathrm{~mL}$. Dipipet sebanyak $25 \mu \mathrm{l}, 50$ $\mu \mathrm{l}, 75 \mu \mathrm{l}, 100 \mu \mathrm{l}, 125 \mu \mathrm{l}$ dicukupkan hingga $1 \mathrm{~mL}$ dapar fosfat dan didapatkan konsentrasi 2,5; 5; 7,5; 10; 12,5 ppm.

\section{Pembuatan Larutan Sampel}

Sampel ditimbang $1 \mathrm{mg}$ dilarutkan dengan DMSO $10 \mu \mathrm{l}$, kemudian disonikasi hingga larut, kemudian ditambahkan dapar fosfat pH 6,8 hingga $10 \mathrm{~mL}$ (konsentrasi $100 \mathrm{ppm}$ ). Dipipet sebanyak $25 \mu \mathrm{l}, 50 \mu \mathrm{l}, 75 \mu \mathrm{l}, 100 \mu \mathrm{l}, 125 \mu \mathrm{l}$ dicukupkan hingga $1 \mathrm{~mL}$ dapar fosfat dan didapatkan konsentrasi 2,5; 5; 7,$5 ; 10 ; 12,5$ ppm.

\section{Prosedur Perlakuan}

\section{Skrining Komponen Senyawa Kimia \\ Uji Alkaloid}

Ekstrak ditambahkan $5 \mathrm{ml} \mathrm{HCl} 2 \mathrm{~N}$ kemudian dipanaskan selama 5 menit kemudian ditambahkan Nacl $5 \mathrm{ml}$ dikocok dan disaring, kemudian ditambahkan $\mathrm{HCl} 2 \mathrm{~N}$ pada masingmasing filtrat, kemudian kocok dan didiamkan. Bagian atas dari masing-masing filtrat diambil dan diuji dengan pereaksi Mayer, Wagner, dan Dragendorf. Terbentuknya endapan jingga, cokelat, dan putih menunjukkan adanya alkaloid (1).

\section{Uji Flavonoid}

Ekstrak sebanyak $1 \mathrm{~mL}$ ditambahkan serbuk Mg 0,1 g dan 3 tetes $\mathrm{HCl}$ pekat. Terbentuknya warna merah bata, orange pada lapisan menunjukkan adanya flavonoid (1).

\section{Uji Terpenoid}

Ekstrak sebanyak $1 \mathrm{ml}$ dicampur dengan $2 \mathrm{ml}$ kloroform dan ditambah $2 \mathrm{ml}$ asam sulfat pekat dan $2 \mathrm{ml}$ asam asetat anhidrat. Perubahan warna kecoklatan antar permukaan menunjukkan adanya senyawa terpenoid (1).

\section{Uji Steroid}

Ekstrak sebanyak $1 \mathrm{ml}$ dicampur dengan $2 \mathrm{ml}$ kloroform dan ditambah $2 \mathrm{ml}$ asam sulfat pekat dan $2 \mathrm{ml}$ asam asetat anhidrat. Perubahan warna dari ungu ke biru atau hijau menunjukkan adanya senyawa steroid (1).

\section{Uji Tanin}

Ekstrak sebanyak $1 \mathrm{~mL}$ dimasukan dalam tabung reaksi kemudian didihkan dengan $10 \mathrm{~mL}$ air di atas penangas air, lalu disaring. Filtrat yang diperoleh ditambahkan 3 tetes $\mathrm{FeCl} 3$ 1\% dan terbentuknya warna coklat kehijauan atau biru kehitaman menunjukkan adanya tanin.

\section{Uji Saponin}

Ekstrak sebanyak $1 \mathrm{~mL}$ dimasukkan kedalam tabung reaksi dan dilarutkan $10 \mathrm{ml}$ aquadest, kemudian dipanaskan, kocok dengan kuat selama 2 menit. Tambahkan 3 tetes $\mathrm{Hcl} 2 \mathrm{~N}$ kemudian kocok dengan kuat. Amati pembentukan busa selama 10 menit. Sampai positif mengandung saponin jika busa konsisten selama 10 menit.

\section{Uji Fenolik}

Ekstrak sebanyak $1 \mathrm{ml}$ ditambahkan beberapa tetes larutan Fecl3 $1 \%$, kemudian di amati warna hijau sampai ungu yang dihasilkan positif mengandung fenolik. 
Proses Pemisahan

Fraksinasi

Ekstrak kental masing-masing ditimban g sebanyak 20 gram dilarutkan menggunakan aquadest $200 \mathrm{~mL}$ (1:10), Selanjutnya filtrat dimasukkan ke dalam corong pisah, ditambahkan n-heksana dengan volume yang sama, dikocok selama 15 menit dan dibiarkan sampai membentuk dua lapisan terpisah yaitu fraksi air dan fraksi n-heksana. Fraksi n-heksan diuapkan, kemudian dilakukan penambahan n-heksana dan pengocokan dilakukan sebanyak lima kali hingga lapisan n-heksan warna bening. Fraksi air dimasukan kembali dalam corong pisah dan ditambah etil asetat dengan volume yang sama, dikocok selama 15 menit dan dibiarkan sampai membentuk dua lapisan terpisah yaitu fraksi air dan fraksi etil asetat. Penambahan etil asetat dan pengocokan dilakukan sebanyak lima kali hingga lapisan etil asetat berwarna bening. Fraksi etil asetat diuapkan pelarutnya. Didapatkan tiga fraksi yaitu fraksi nheksan, fraksi etil asetat dan fraksi air. Fraksi yang diperoleh kemudian dilakukan uji aktivitas penghambatan $\alpha$ glukosidase. Fraksi yang aktif dari hasil partisi Kemudian dilakukan orientasi eleun dengan KLT untuk dilakukan proses pemisahan dengan kromatografi kolom vakum.

\section{Uji Aktivitas Penghambatan Enzim a-Glukosidase Pengujian Blanko}

Larutan dapar fosfat pH 6,8 sebanyak $70 \mu \mathrm{L}$ dicampur. Lalu ditambahkan $15 \mu \mathrm{L}$ substrat $\mathrm{p}$-nitrofenil- $\alpha$-D lukopiranosida (pNPG) dalam well 96, kemudian diinkubasi selama 5 menit ada suhu $37^{\circ} \mathrm{C}$. Kemudian ditambahkan $15 \mu \mathrm{L}$ enzim $\alpha-$ glukosidase $0,5 \mathrm{U} / \mathrm{mL}$. Campuran diinkubasi selama 15 menit pada suhu $37^{\circ} \mathrm{C}$. Setelah masa inkubasi selesai ditambahkan $100 \mu \mathrm{L}$ Natrium karbonat. Sampel diukur absorbansinya pada panjang gelombang $405 \mathrm{~nm}$. Pengujian dilakukan tiga kali replikasi.

\section{Pengujian Kontrol Negatif}

Larutan $10 \mu \mathrm{L}$ DMSO dan dapar fosfat pH 6,8 sebanyak $60 \mu \mathrm{L}$ dicampur. Lalu ditambahkan $15 \mu \mathrm{L}$ substrat p-nitrofenil- $\alpha$-D glukopiranosida (pNPG) dalam well 96, kemudian diinkubasi selama 5 menit pada suhu $37^{\circ} \mathrm{C}$. Kemudian ditambahkan 15 $\mu \mathrm{L}$ enzim $\alpha$-glukosidase $0,5 \mathrm{U} / \mathrm{mL}$. Campuran diinkubasi selama 15 menit pada suhu $37^{\circ} \mathrm{C}$. Setelah masa inkubasi selesai ditambahkan $100 \mu \mathrm{L}$ Natrium karbonat. Sampel diukur absorbansinya pada jang gelombang $405 \mathrm{~nm}$. Pengujian dilakukan tiga kali replikasi.

\section{Pengujian Kontrol Positif}

Dari konstrasi dipipet $30 \mu \mathrm{l}$ larutan acarbose ditambah $60 \mu \mathrm{l}$ dapar fosfat $\mathrm{pH}$ 6,8 dan ditambahkan $15 \mu \mathrm{l}$ substrat pNPG 5 mM dalam well 96. Campuran tersebut diinkubasi selama 5 menit pada suhu $37^{\circ} \mathrm{C}$. Kemudian, ditambahkan $15 \mu \mathrm{l}$ larutan enzim $0,5 \mathrm{U} / \mathrm{mL}$ diinkubasi lagi selama15 menit suhu $37^{\circ} \mathrm{C}$. Setelah selesai diinkubasi ditambahakn $100 \mu \mathrm{l}$ natrium karbonat. Diukur absorbansinya dengan pada panjang gelombang $405 \mathrm{~nm}$. pengujian dilakukan tiga kali replikasi.

\section{Pengujian Sampel Ekstrak dan Fraksi}

Fraksi aktif diambil $30 \mu \mathrm{L}$. Reaksi enzim dihentikan dengan penambahan larutan $\mathrm{Na}_{2} \mathrm{CO}_{3} 200$ mM. pNPG diambil sebanyak $15 \mu \mathrm{L}$ dari masing-masing konsentrasi 5, 10, 15, $20 \mathrm{mM}$ kemudian ditambahkan dapar posfat $40 \mu \mathrm{L}$ dalam well 96 . Campuran tersebut diinkubasi selama 5 menit pada suhu $37^{\circ} \mathrm{C}$ Kemudian ditambahkan $15 \mu \mathrm{l}$ larutan enzim 0,5 U/mL diinkubasi lagi selama15 menit suhu $37^{\circ} \mathrm{C}$. Setelah selesai diinkubasi ditambahkan $100 \mu \mathrm{l}$ natrium karbonat. Diukur absorbansinya dengan pada panjang gelombang $405 \mathrm{~nm}$. pengujian dilakukan tiga kali replikasi.

Persentase penghambatan aktivitas $\alpha$-glukosidase dapat dihitung melalui rumus:

$$
\% \text { Inhibisi }=\left[\frac{\left(A_{0}-A_{1}\right)}{A_{0}}\right] \times 100 \%
$$

$\mathrm{A}_{0}=$ Absorbansi Blanko

$\mathrm{A}_{1}=$ Absorbansi Sampel

Melalui persamaan regresi linier, $\mathrm{y}=\mathrm{a}+\mathrm{bx}$, dimana sumbu $\mathrm{x}$ adalah konsentrasi sampel dan sumbu y adalah \% inhibisi, maka nilai IC50 dapat dihitung menggunakan rumus:

$$
I C_{50}=\frac{50-a}{b}
$$

Pengolahan dan Analisis Data

Penelitian ini menggunakan data primer yang berasal dari hasil pemisahan, dan uji aktivitas.

\section{HASIL DAN PEMBAHASAN}

Pada penelitian ini, simplisia yang digunakan adalah daun sambung nyawa (G. procumbens) yang diperoleh dari daerah padang-padang Kecamatan Belopa kabupaten luwuk dan telah dideterminasi di Herbarium Bogoriense (LIPI) Bogor, dengan tujuan untuk memastikan bahwa daun tersebut adalah bagian dari tanaman daun sambung nyawa. Daun yang digunakan adalah daun yang berwarna hijau dan masih segar.

Daun G. procumbens yang diperoleh kemudian disortasi, dipisahkan dari pengotor-pengotor, setelah itu dilakukan penimbangan berat daun sambung nyawa, selanjutnya dikeringkan menggunakan lemari pengering simplisia suhu \pm $40^{\circ} \mathrm{C}$. Simplisia sebanyak 1000 gram diekstraksi dengan metode maserasi menggunakan pelarut etanol $70 \%$, selama $3 \times 24$ jam. Pelarut etanol 70\% digunakan karena etanol cenderung aman, tidak beracun dan tidak berbahaya. Selanjutnya residu dilakukan remaserasi dengan pelarut yang sama selama $1 \times 24$ jam. Filtrat yang didapatkan kemudian di evaporasi pelarutnya pada suhu $40^{\circ} \mathrm{C}$ sehingga didapatkan ekstrak kental, selanjutnya berat ekstrak kental ditimbang adapun persen rendamen yang didapat $4,8 \%$

Hasil diidentifikasi golongan senyawa kimia. Berdasarkan uji identifikasi golongan senyawa kimia yang telah dilakukan hasil menunjukkan bahwa ekstrak etanol $70 \%$ positif mengandung, flavanoid, saponin, steroid, terponoid, tanin dan fenolik.

Pada pengujian selanjutnya dilakukan penentuan aktivitas inhibitor dari ekstrak etanol terhadap $\alpha$-glukosidase Hasil penghambatn ekstrak etanol dan acarbose memiliki kemampuan aktivitas menghambat $\alpha$-glukosidase dengan nilai IC50 sebesar 6,56 ppm dan 6,39 ppm (Gambar 1).

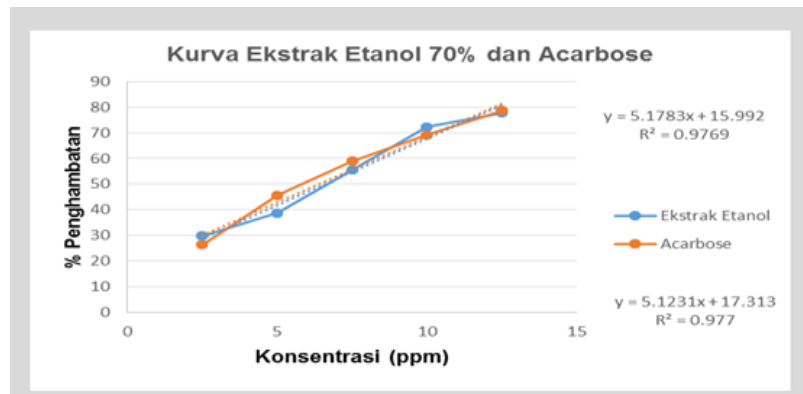

Gambar 1. Grafik Persentasi Penghambatan Ekstrak dan Acarbose

Hasil fraksinasi diperoleh fraksi n-heksan berwarna hijau kecoklatan dengan berat 3,276 g, fraksi etil asetat berupa fraksi pekat berwarna hijau tua kehitaman dengan berat $11,023 \mathrm{~g}$ dan fraksi air berwarna kuning kecoklatan dengan berat 4,402 g. Selanjutnya dari hasil 3 fraksi yang didapatkan dilakukan pengujian aktivitas penghambatan $\alpha$-glukosidase dengan variasi konsentrasi yang digunakan sama dengan konsentrasi yang digunakan pada ekstrak dan acarbose. Hal 
ini digunakan untuk memperoleh nilai persen inhibisi yang diguanakan untuk menghitung nilai IC50 (konsentrasi yang dibutuhkan untuk menghambat $50 \%$ aktivitas enzim) dari setiap fraksi dan nilai IC50 tersebut digunakan untuk mengetahui kekuatan penghambatan fraksi terhadap enzim. Fraksi yang memiliki nilai IC50 paling rendah merupakan fraksi yang memiliki kemampuan menghambat aktivitas $\alpha$ glukosidase paling tinggi, dari ke 3 fraksi yang memiliki daya hambat yaitu fraksi etil asetat dengan aktivitas penghambatan sebesar 9,33 ppm. (gambar 2)

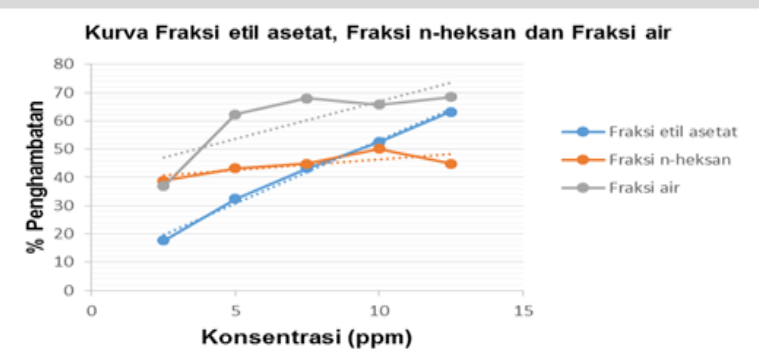

Gambar 1. Grafik Persentasi Penghambatan Fraksi Etil Asetat, Fraks n-Heksan dan Fraksi Air

\section{KESIMPULAN}

Berdasarkan hasil penelitian fraksi penghambstsn enzim $\alpha$ glukosidase menunjukan bahwa nilai $\mathrm{IC}_{50}$ berturut-turut pada ekstrak etanol 6,56 ppm, fraksi n-heksan sebesar 14,97 ppm, fraksi etil asetat 9,33 ppm, fraksi air 13,03 ppm dan acarbose 6,38 ppm serta mekanisme kinetika penghambatan enzim secara uncompetitive.

\section{UCAPAN TERIMA KASIH}

Penulis mengucapkan terima kasih kapada kedua orang tua. Penulis juga berterima kasih kepada pembimbing dan Penulis juga berterima kasih kepada Fakultas Farmasi Universitas Hasanuddin dan STIFA-AKFAR Makassar atas dukungan moril dan sarana selama penulis melakukan penelitian.

\section{DAFTAR PUSTAKA}

1. Thomas, Tanaman Obat Tradisional I, Penerbit Kanisius, Yogyakarta. 1993

2. Thomas, A.N.S. Tanaman Obat Tradisional I. Yogyakarta. Kanisius. 1989

3. Rosidah, Mun F, Amirin A., Gabriel A., Zaini A. Toxicology evaluation of standardized methanol extract of Gynura procumbens. Journal of Ethnopharmacology; 2009, p. 244-9

4. Dipiro JosephT. Robert L, Talbert, Gary C., Yees., Gary R. Matzke. Barbara G. Wells.,\& L., Michael Posey. Pharmacotherapy A Pathopysiologic Approach. New York: McGraw-Hill; 2008, P.2

5. World Health Organization. The world health report 2007: a safer future. Global Public Health.; 2007. p.96.

6. Muchid, A., F. Umar, M. N. Ginting, C. Basri, R. Wahyuni, R. Helmi, dan S. N. Istiqomah. Pharmaceutical care untuk penyakit diabetes mellitus. Departemen Kesehatan RI ;2005, p.1-89.

7. Zhang X.F. \& Tan,B.K.H. Effects of an Ethanolic Extract of Gynura procumbens on Serum Glucose, Cholesterol, and Triglyceride Levels in Normal and Streptozotocin-Induced Diabetic Rats, Singapore Medical Journal, 2000, 41 (1);p.9 